${ }^{1}$ U.S. Department of Agriculture, Agricultural Research Service, Beltsville, MD, USA,

${ }^{2}$ University Munich, Livestock Center, Oberschleißheim, Germany

A.D. MITCHELL ${ }^{1}$ and A.M. SCHOLZ ${ }^{2}$

\title{
Efficiency of energy and protein deposition in swine measured by dual energy X-ray absorptiometry (DXA) ${ }^{\S}$
}

\begin{abstract}
A series of studies were conducted using dual energy X-ray absorptiometry (DXA) to measure energy and protein deposition in pigs. In an initial validation study DXA was compared directly with slaughter analysis as a method for measuring energy deposition in pigs. During growth from 30 to $60 \mathrm{~kg}$ the mean value for carcass energy deposition measured by DXA was $251 \mathrm{MJ}$ compared to $249 \mathrm{MJ}$ by chemical analysis $\left(\mathrm{R}^{2}=0.94\right)$. Subsequently it was shown that both compensatory growth and the addition of ractopamine to the diet resulted in an improvement in efficiency of protein deposition (PE), however, ractopamine also resulted in a reduction in the efficiency of energy deposition ( $\mathrm{k}_{\mathrm{g}}$ ). Another study was conducted to compare the efficiency of utilization of dietary energy and protein by control and IGF-I transgenic pigs in response to dietary conjugated linoleic acid (CLA). Addition of CLA to the diet resulted in a reduction in $\mathrm{k}_{\mathrm{g}}$, though there was no difference in $\mathrm{k}_{\mathrm{g}}$ based on genotype or sex. The $\mathrm{PE}$ was higher $(\mathrm{P}<0.05)$ in the IGF-I transgenic pigs. DXA was also used to assess energy deposition in pigs that were either homozygous stress non-sensitive $(N N)$, heterozygous $(N n)$ or homozygous stress sensitive $(n n)$. During growth from 30 to $60 \mathrm{~kg}$ or 60 to $90 \mathrm{~kg}$ there were no differences in the efficiency of either energy or protein deposition. In conclusion, DXA can be used to replace the comparative slaughter technique for measuring energy and protein deposition in pigs, thus this approach is useful for identifying differences in energy and protein deposition in pigs of different genotypes or when subjected to various dietary treatments.
\end{abstract}

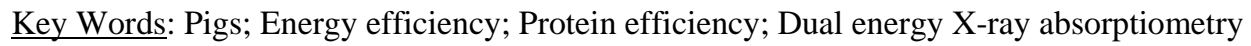

\section{Zusammenfassung}

Titel der Arbeit: Messung der Effizienz des Energie- und Proteinansatzes von Schweinen mittels DualenergieRöntgenabsorptiometrie (DXA)

Eine Reihe von Dualenergie-Röntgenabsorptiometrie-Studien diente der Messung des Energie- und Proteinansatzes in Schweinen. In einem Vorversuch zur Messung des Energieansatzes wurden die DXA-Ergebnisse direkt mit den Ergebnissen der Schlachtkörperanalyse verglichen. Während des Wachstums zwischen 30 und 60 kg Körpermasse betrug der mittels DXA ermittelte Mittelwert für den „Schlachtkörper“-Energieansatz 251 MJ im Vergleich zu 249 MJ aus der chemischen Analyse $\left(\mathrm{R}^{2}=0.94\right)$. In einer Folgestudie konnte gezeigt werden, dass sowohl kompensatorisches Wachstum als auch der Zusatz von Raktopamin zur Ration eine Verbesserung der Effizienz des Proteinansatzes (PE) bewirkten. Der Zusatz von Raktopamin führte jedoch gleichzeitig zu einer Verminderung der Effizeinz des Energieansatzes $\left(\mathrm{k}_{\mathrm{g}}\right)$. Eine weitere Studie diente dem Vergleich von Kontroll- und IGF-I transgenen Schweinen in Bezug auf die Effizienz der Verwertung von Nahrungsenergie und -protein nach Einsatz von konjugierter Linolsäure (CLA) in der Ration. Der Zusatz von CLA resultierte in einer Verminderung von $k_{g}$, während in Bezug auf Genotyp oder Geschlecht keine Differenz für $\mathrm{k}_{\mathrm{g}}$ auftrat. PE war jedoch in den IGF-I transgenen Schweinen höher $(\mathrm{P}<0.05)$. DXA wurde außerdem eingesetzt, um den Energieansatz von Schweinen zu untersuchen, die sich am Ryanodinrezeptor-Genort unterschieden (mit $N N$ = homozygot „stressstabil“, $N n=$ heterozygot oder $n n=$ homozygot „stressanfällig“). Während des Wachstums zwischen 30 und 60 kg bzw. zwischen 60 und $90 \mathrm{~kg}$ Lebendmasse zeigten sich weder Differenzen in der Effizienz des Energie- noch des Proteinansatzes. Schlussfolgernd kann DXA als Ersatz für Vergleichsschlachtungen eingesetzt werden, um den Energie- und

${ }^{\S}$ Mention of a trade names or companies does not constitute an implied warranty or endorsement by the USDA or the authors. 
Proteinansatz zu messen. Mit dieser Technik lassen sich Differenzen im Energie- und Proteinansatz bei Schweinen verschiedener Genotypen oder in Abhängigkeit von der Rationsgestaltung feststellen.

Schlüsselwörter: Schweine; Energieeffizienz; Proteineffizienz; Dualenergie-Röntgenabsorptiometrie

\section{Introduction}

Valid measurements of energy and protein deposition based on changes in body composition require accurate determination of body composition at both the beginning and end of the experimental period. Traditionally, these changes in body composition have been determined by the comparative slaughter technique (KYRIAZAKIS and EMMANS, 1992; BIKKER et al., 1995). Recently it has been shown that DXA can be used in conjunction with genetic and nutritional studies in swine to evaluate differences in body composition (MITCHELL and SCHOLZ, 1997; MITCHELL et al., 2002: OSTROWSKA et al., 2003; MITCHELL et al., 2005; SCHOLZ and FÖRSTER, 2006). The purpose of the studies reported here was to validate the use of DXA for measuring energy and protein deposition and to apply this approach to pigs of different genetic backgrounds and exposed to various nutritional treatments.

Following a period of restricted dietary intake, young pigs exhibit compensatory growth that is characterized by an accelerated growth rate that usually includes more fat and less muscle than in pigs continuously fed ad libitum (MERSMANN et al., 1987). Fat and lean deposition in growing pigs can also be influenced by the level of protein in the diet and by feeding the $\beta$-adrenergic agonist, ractopamine (MITCHELL et al., 1990; SAGGAU et al., 2000; SCHOLZ and FÖRSTER, 2006; CARR et al., 2005). Thus, studies were conducted to examine the effects of controlled intake, dietary protein level, and ractopamine supplementation on growth, body composition, and the efficiency of energy and protein deposition in pigs during uninterrupted or compensatory growth from 60 to $100 \mathrm{~kg}$.

Conjugated linoleic acid (CLA), when added to the diets of mice and pigs, reduces fat deposition and increases lean tissue mass (PARK et al. 1997; DUGAN et al. 1997). In mice, the reduced fat deposition has been attributed to an increase in energy expenditure (WEST et al. 2000; TERPSTRA et al. 2002). However, an increase in energy expenditure was not observed in pigs and hamsters fed CLA (MULLER et al. 2000; BOUTHEGOURD et al., 2002). Pigs expressing the skeletal $\alpha$-actin-hIGF-I transgene deposit less fat and more lean than their littermate controls (PURSEL et al. 2001). A part of this study aimed at the measurement of the efficiency of energy and protein accretion in control and IGF transgenic pigs fed diets with or without CLA added.

Malignant hyperthermia, the condition associated with a mutation in the DNA sequence encoding the function of the ryanodine receptor 1 (FUJII et al., 1991), results in changes in energy metabolism. The most dramatic changes occur in pigs exposed to stress. In vivo ${ }^{31} \mathrm{P}-\mathrm{NMR}$ studies have demonstrated halothane induced depletion in muscle ATP and phosphocreatine and accumulation of inorganic phosphate in homozygous stress sensitive (nn) pigs (GEERS et al., 1992; SCHOLZ et al., 1995) with moderate responses occurring in heterozygous $(\mathrm{Nn})$ pigs (SCHOLZ et al., 1995). Evidence of alteration in energy metabolism under resting conditions is suggested by higher plasma glucose concentrations (OTTEN et al., 1993) and higher intramuscular concentrations of 
phosphocreatine (DECANNIERE et al., 1993) and phoshpomonoesters (GEERS et al., 1996). In the long term, these changes in energy metabolism may be associated with decreased lipid deposition and an altered efficiency of the utilization of dietary energy for tissue growth. Another part of this study series used DXA to monitor in vivo changes in body composition and energy deposition in pigs of different ryanodine receptor 1 genotypes.

\section{Validation study}

Material and methods

A total of 24 pigs were used in the study. Starting at $10 \mathrm{~kg}, 12$ pigs were fed a $12 \%$ protein diet $(15.36 \mathrm{MJ} / \mathrm{kg}$ ) and 12 pigs were fed an $18 \%$ protein diet $(14.77 \mathrm{MJ} / \mathrm{kg})$ to induce moderate differences in body composition. At 30, 40, 50 and $60 \mathrm{~kg}$, three pigs from each diet were killed and then scanned by DXA (Lunar DPXL). Following the scanning procedure, the bodies of the pigs were frozen. Later, the GI tract was removed and the carcass was homogenized by grinding. The lipid and protein content of the ground carcass were measured by chemical analysis. Composition of the two groups of $30 \mathrm{~kg}$ pigs served as the starting point for energy deposition measurements.

\section{RAC studies}

Eight groups of pigs (four groups of barrows, $R A C-B$ and four groups of females, $R A C-F$; 54 pigs in total) were scanned by DXA (Lunar Prodigy) for body composition analysis at a starting weight of $60 \mathrm{~kg}$ and at a final weight of $100 \mathrm{~kg}$. Four groups of pigs (two groups of barrows and two groups of females) were fed at continuous intake levels from $60 \mathrm{~kg}$ : ad libitum (A) the basal diet (186 g/kg CP and $13.58 \mathrm{MJ} / \mathrm{kg} \mathrm{ME}$ ), ad libitum plus 20 $\mathrm{mg} / \mathrm{kg}$ ractopamine (R). Four groups of pigs (two groups of barrows and two groups of females) were maintained at $60 \mathrm{~kg}$ for $56 \mathrm{~d}$, scanned by DXA again, and then fed: ad libitum intake (M-A), and ad libitum intake plus R (M-R).

\section{PROT study}

Three groups of pigs (24 pigs in total) were scanned by DXA (Lunar Prodigy) for body composition analysis at a starting weight of $60 \mathrm{~kg}$ and at a final weight of $100 \mathrm{~kg}$. One group was fed at continuous intake levels from $60 \mathrm{~kg}$ the basal diet $(186 \mathrm{~g} / \mathrm{kg} \mathrm{CP}$ and $13.58 \mathrm{MJ} / \mathrm{kg} \mathrm{ME}$ ), limited at calculated (C) energy intake level (NRC, 1988). Two groups were maintained at $60 \mathrm{~kg}$ for $56 \mathrm{~d}$, scanned by DXA again, and then one group was fed $200 \mathrm{~g} / \mathrm{kg} \mathrm{CP}$ (13.73 MJ/kg ME) diet at C intake (M-HP) and the other was fed $120 \mathrm{~g} / \mathrm{kg}$ CP (13.79 MJ/kg ME) diet at C intake (M-LP).

\section{TG/CLA study}

Transgenic pigs were produced with a fusion gene composed of avian skeletal $\alpha$-actin regulatory sequences and the cDNA encoding IGF-I (PURSEL et al., 2004). Transgenic (T) and sibling control (C) progeny were produced by mating two half-sib G-1 transgenic boars to non-transgenic gilts. At $60 \mathrm{~kg}$, each pig was scanned by DXA (Lunar DPXL) for body composition analysis, then placed on a diet with a CP content of $182 \mathrm{~g} / \mathrm{kg}$, a ME 
content of $13.8 \mathrm{MJ} / \mathrm{kg}$, and supplemented with either corn oil at $20 \mathrm{~g} / \mathrm{kg}$ (CO diet) or CO at $10 \mathrm{~g} / \mathrm{kg}$ plus CLA at $10 \mathrm{~g} / \mathrm{kg}$ (CLA diet). Thus, the four genotype-diet combinations were: C-CO $(n=25)$, C-CLA $(n=25), T-C O(n=24)$, and T-CLA $(n=23)$. Distributed among these were 54 females and 43 barrows. Total feed intake was measured for each pig individually. Each pig was scanned again by DXA at $110 \mathrm{~kg}$.

\section{RRG study}

A total of 32 pigs were evaluated by live DXA (Lunar DPXL) scanning at 30 and $60 \mathrm{~kg}$ ( $R R G-60)$. The pigs were identified by the ryanodine receptor (RYR1) gene test described by BRENIG and BREM (1992) as being either homozygous stress non-sensitive (NN, 14 pigs), heterozygous ( $N n, 11$ pigs) or homozygous stress sensitive ( $n n, 7$ pigs). In addition, sixteen of these pigs ( $N N, 6$ pigs; $N n, 6$ pigs; $n n, 4$ pigs) were scanned again at $90 \mathrm{~kg}(R R G-90)$.

\section{DXA scanning}

Diet was withheld for 18 hours prior to scanning and, immediately prior to scanning, each pig was weighed on an electronic scale $( \pm 0.2 \mathrm{~kg})$. Each pig was placed on the instrument in a prone position and a total body scan was performed. All pigs were anesthetized. The DXA scans were performed using either the Lunar DPXL or the Lunar Prodigy densitometer as noted above. Estimates of energy deposition were based on DXA measurements of total body fat and total body protein calculated from DXA lean body mass measurements. The use of DXA for measuring total body fat and protein of pigs within this range in body size has been validated through slaughter and chemical analysis of pigs from this and other studies (MITCHELL et al., 1996).

Total body protein was calculated from the DXA lean values using the following equation: protein $(g)=-1.062+(0.2 \cdot \mathrm{DXA}$ lean). Feed intake was measured for each pig individually. Total body fat and protein deposition were based on the differences between the initial and final DXA measurements of fat and lean. The energy content of the carcass was calculated assuming $23.765 \mathrm{MJ} / \mathrm{kg}$ as the energy value for body protein (KLEIBER, 1961) and 39.581 MJ/kg as the value for body fat (SAINZ and WOLFF, 1988).

\section{Statistics}

Statistical analysis was performed using Statgraphics Plus ${ }^{\circledR}$ for Windows 2.1. Differences between means were evaluated by analysis of variance followed by a multiple range test (LSD at 95\% confidence interval). Linear regression analysis (Sigma Plot ${ }^{\circledR}$ 7.0) was used to compare the relationship between the rate of fat deposition and the efficiency of energy deposition, the rate of protein deposition and the efficiency of protein deposition, and energy intake and efficiency of protein deposition.

\section{Validation study}

Results and discussion

The results for the measurement of total body fat by both DXA and chemical analysis are shown in Tab. 1. There was close agreement between the two methods, with both showing a progressive increase in body fat (percent and total) as the weight of the pigs 
increased from 30 to $60 \mathrm{~kg}$, and a consistent difference between pigs fed diets containing 12 or $18 \%$ protein. The measurements of total carcass fat $(\mathrm{kg})$ by the two methods were highly correlated $\left(\mathrm{R}^{2}=0.97\right)$. Comparing the mean values of all pigs for either percent fat or as lipid contribution to total carcass energy content (MJ), there was no significant difference $(\mathrm{P}>.05)$ between chemical and DXA measurements. A comparison of chemical and DXA values for the percent protein and the calculated protein contribution to total body energy content is also shown in Table 1 . By both methods, a significant difference $(\mathrm{P}<0.05)$ was observed for carcass protein $(\%$ or $\mathrm{MJ})$ as a result of the dietary treatments. For pigs fed the $18 \%$ protein diet, the DXA estimate of \% protein in the carcass was slightly higher than the chemical value, however for pigs fed the $12 \%$ protein diet the DXA estimate was significantly lower $(\mathrm{P}<.05)$ than the chemical value. These differences also appeared when expressed as total protein content, but were not significant $(\mathrm{P}>0.05)$.

Table 1

Chemical and DXA measurements of carcass fat and protein content and contribution to total carcass energy content (means of 3 pigs/weight-diet group) (Chemische und DXA-Messergebnisse für Schlachtkörperfett- und -proteingehalt sowie jeweiliger Anteil am Schlachtkörperenergiegehalt (Mittelwerte aus 3 Schweinen pro Gewicht-Rations-Gruppe))

\begin{tabular}{|c|c|c|c|c|c|c|c|c|c|c|c|}
\hline \multirow{2}{*}{$\begin{array}{l}\text { Weight } \\
\text { Group }\end{array}$} & \multirow[b]{2}{*}{ Diet } & \multicolumn{2}{|l|}{$\%$ Fat } & \multicolumn{2}{|c|}{ Fat (MJ) } & \multicolumn{2}{|c|}{ \% Protein } & \multicolumn{2}{|c|}{ Prot (MJ) } & \multicolumn{2}{|c|}{ Total (MJ) } \\
\hline & & Chem & DXA & Chem & DXA & Chem & DXA & Chem & DXA & Chem & DXA \\
\hline \multirow[t]{2}{*}{30} & 12 & 20.1 & 18.5 & 227 & 208 & 13.5 & 13.2 & 92 & 90 & 319 & 298 \\
\hline & 18 & 13.0 & 14.1 & 154 & 167 & 14.1 & 15.2 & 100 & 108 & 254 & 275 \\
\hline \multirow[t]{2}{*}{40} & 12 & 22.0 & 20.3 & 357 & 329 & 14.2 & 13.6 & 133 & 133 & 495 & 462 \\
\hline & 18 & 14.9 & 15.0 & 234 & 237 & 14.9 & 15.6 & 148 & 148 & 375 & 385 \\
\hline \multirow[t]{2}{*}{50} & 12 & 20.7 & 21.9 & 420 & 444 & 14.9 & 13.4 & 164 & 164 & 602 & 608 \\
\hline & 18 & 17.1 & 17.7 & 357 & 370 & 15.3 & 15.8 & 199 & 199 & 549 & 569 \\
\hline \multirow[t]{2}{*}{60} & 12 & 23.0 & 22.6 & 531 & 520 & 14.1 & 13.4 & 185 & 185 & 725 & 705 \\
\hline & 18 & 16.4 & 18.0 & 393 & 431 & 15.8 & 15.4 & 221 & 221 & 621 & 652 \\
\hline Mean & 12 & 21.5 & 20.8 & 384 & 376 & 14.2 & $13.4^{*}$ & 142 & 142 & 535 & 518 \\
\hline$(n=12)$ & 18 & 15.4 & 16.2 & 285 & 297 & 15.0 & 15.5 & 169 & 169 & 450 & 470 \\
\hline Mean & & & & & & & & & & & \\
\hline$(n=24)$ & All & 18.5 & 18.5 & 334 & 338 & 14.6 & 14.5 & 156 & 156 & 493 & 494 \\
\hline
\end{tabular}

*Chem and DXA values were different at $\mathrm{P}<.05$.

When the mean values for all pigs were compared (combining 12 and 18\% protein diet treatments), there was no difference between the DXA and chemical measurements of carcass protein. Starting at $30 \mathrm{~kg}$, the amount of energy deposited in the carcass and the efficiency of retention of dietary energy in the carcass were calculated for both chemical and DXA measurements of total carcass energy (Tab. 2). Generally, there was good agreement between results obtained by the two methods and both showed the same pattern with respect to differences due to diet and weight group. 
Table 2

Carcass energy gain (MJ) and efficiency $\left(\mathrm{K}_{\mathrm{g}}\right)$ of retention of dietary energy in the carcass, starting from $30 \mathrm{~kg}$ (means of 3 pigs/wt-diet group) (Schlachtkörperenergieansatz (MJ) and Effizienz $\left(\mathrm{K}_{\mathrm{g}}\right)$ der Nahrungsenergie-Retention im Schlachtkörper ab 30 kg Lebendmasse (Mittelwerte aus 3 Schweinen pro Gewicht-Rations-Gruppe))

\begin{tabular}{|c|c|c|c|c|c|c|c|c|}
\hline \multirow{3}{*}{$\begin{array}{l}\text { Weight } \\
\text { Group }\end{array}$} & \multicolumn{4}{|c|}{ Carcass energy gain (MJ) } & \multicolumn{4}{|c|}{ Energy efficiency $\left(\mathrm{K}_{\mathrm{g}}\right)$} \\
\hline & \multicolumn{2}{|c|}{ Diet 12} & \multicolumn{2}{|c|}{ Diet 18} & \multicolumn{2}{|c|}{ Diet 12} & \multicolumn{2}{|c|}{ Diet 18} \\
\hline & Chem & DXA & Chem & DXA & Chem & DXA & Chem & DXA \\
\hline 40 & 150 & 140 & 103 & 89 & 31.3 & 29.2 & 34.7 & 30.1 \\
\hline 50 & 231 & 261 & 276 & 273 & 28.8 & 32.7 & 35.0 & 34.6 \\
\hline 60 & 381 & 384 & 350 & 359 & 36.0 & 36.3 & 38.2 & 39.2 \\
\hline \multicolumn{8}{|l|}{ Mean } & \\
\hline
\end{tabular}

Efficiency of energy and protein deposition

The effects of various dietary and genetic factors on the efficiencies of energy $\left(\mathrm{k}_{\mathrm{g}}\right)$ and protein (PE) deposition are shown in Tab. 3. When pigs were fed ad libitum, ractopamine (RAC study) resulted in an improvement in PE in both groups (A-R and MA-R), but not in $\mathrm{k}_{\mathrm{g}}$. Similarly, compensatory growth in the ad libitum intake pigs (MA and MA-R) had no effect on $\mathrm{k}_{\mathrm{g}}$, but resulted in a significant improvement in $\mathrm{PE}(0.26$ vs. $0.20, \mathrm{P}<0.05)$.

Table 3.

Energy and protein intake, deposition and efficiency of deposition (Energie- und Proteinaufnahme, -ansatz und -ansatzeffizienz)

\begin{tabular}{|c|c|c|c|c|c|c|c|}
\hline \multirow{2}{*}{$\frac{\text { Description }}{\text { Study/Group }}$} & \multirow[b]{2}{*}{$\operatorname{Sex}^{\S} /(\mathrm{n})$} & \multicolumn{2}{|c|}{$\underline{\text { Intake }}$} & \multicolumn{2}{|c|}{ Deposition $^{¥}$} & \multicolumn{2}{|c|}{ Efficiency of deposition ${ }^{*}$} \\
\hline & & $\begin{array}{l}\text { Energy } \\
(\mathrm{MJ} / \mathrm{d})\end{array}$ & $\begin{array}{l}\text { Protein } \\
\text { (g/d) }\end{array}$ & $\begin{array}{l}\text { Fat } \\
(\mathrm{g} / \mathrm{d})\end{array}$ & $\begin{array}{l}\text { Protein } \\
\text { (g/d) }\end{array}$ & $\begin{array}{l}\text { Energy } \\
\left(\mathrm{K}_{\mathrm{g}}\right)\end{array}$ & $\begin{array}{l}\text { Protein } \\
(\mathrm{PE})\end{array}$ \\
\hline \multicolumn{8}{|l|}{$R A C-B$} \\
\hline A & B(8) & $46.31 \pm 1.04$ & $637 \pm 14$ & $338 \pm 15 b$ & $109 \pm 7 a$ & $0.345 \pm 0.016 b$ & $0.171 \pm 0.016 \mathrm{a}$ \\
\hline MA & B(9) & $46.18 \pm 0.98$ & $635 \pm 13$ & $266 \pm 14 a$ & $139 \pm 7 b$ & $0.301 \pm 0.015 a$ & $0.221 \pm 0.015 b$ \\
\hline A-R & B(9) & $52.11 \pm 0.98$ & $716 \pm 13$ & $337 \pm 14 b$ & $155 \pm 7 b$ & $0.327 \pm .015 \mathrm{ab}$ & $0.217 \pm 0.015 b$ \\
\hline MA-R & B(8) & $50.67 \pm 1.04$ & $696 \pm 14$ & $284 \pm 15 a$ & $208 \pm 7 c$ & $0.319 \pm 0.016 \mathrm{ab}$ & $0.301 \pm 0.016 c$ \\
\hline \multicolumn{8}{|l|}{$R A C-F$} \\
\hline A & $F(5)$ & $38.75 \pm 1.32$ & $533 \pm 17$ & $262 \pm 19 b$ & $96 \pm 9 a$ & $0.332 \pm 0.021 b$ & $0.181 \pm 0.020 \mathrm{a}$ \\
\hline MA & $F(5)$ & $39.21 \pm 1.32$ & $539 \pm 17$ & $208 \pm 19 a b$ & $136 \pm 9 a b$ & $0.293 \pm 0.021 \mathrm{ab}$ & $0.252 \pm 0.020 \mathrm{ab}$ \\
\hline A-R & $F(5)$ & $47.01 \pm 1.32$ & $646 \pm 17$ & $220 \pm 19 a b$ & $132 \pm 9 a b$ & $0.252 \pm 0.021 \mathrm{a}$ & $0.205 \pm 0.020 \mathrm{ab}$ \\
\hline MA-R & $F(5)$ & $46.85 \pm 1.32$ & $644 \pm 17$ & $182 \pm 19 a$ & $173 \pm 9 b$ & $0.241 \pm 0.021 \mathrm{a}$ & $0.269 \pm 0.020 \mathrm{~b}$ \\
\hline \multicolumn{8}{|l|}{ PROT } \\
\hline C & B(8) & $38.28 \pm 1.04$ & $526 \pm 14$ & $249 \pm 15 a$ & $145 \pm 7 b$ & $0.348 \pm 0.016 a$ & $0.276 \pm 0.016 a$ \\
\hline MC-HP & $\mathrm{B}(8)$ & $38.31 \pm 1.04$ & $560 \pm 14$ & $246 \pm 15 a$ & $139 \pm 7 a b$ & $0.341 \pm 0.016 a$ & $0.253 \pm 0.016 a$ \\
\hline MC-LP & $\mathrm{B}(8)$ & $38.73 \pm 1.04$ & $337 \pm 14$ & $309 \pm 15 b$ & $116 \pm 7 a$ & $0.390 \pm 0.016 b$ & $0.350 \pm 0.016 b$ \\
\hline MC-LP* & & & & & & $0.343 \pm 0.016 \mathrm{a}$ & $0.261 \pm 0.016 a$ \\
\hline \multicolumn{8}{|l|}{$T G-C L A$} \\
\hline C-CO & $\mathrm{B}(10) \mathrm{F}(15)$ & $41.89 \pm 0.58$ & $553 \pm 7$ & $314 \pm 9 b$ & $117 \pm 7 a$ & $0.364 \pm 0.010 \mathrm{~b}$ & $0.211 \pm 0.008 a$ \\
\hline C-CLA & $\mathrm{B}(12) \mathrm{F}(13)$ & $41.82 \pm 0.58$ & $552 \pm 7$ & $268 \pm 9 a$ & $120 \pm 6 a$ & $0.324 \pm 0.010 \mathrm{a}$ & $0.222 \pm 0.008 a$ \\
\hline T-CO & $\mathrm{B}(10) \mathrm{F}(13)$ & $40.87 \pm 0.61$ & $540 \pm 8$ & $266 \pm 9 a$ & $127 \pm 7 b$ & $0.339 \pm 0.010 \mathrm{ab}$ & $0.257 \pm 0.009 b$ \\
\hline T-CLA & $\mathrm{B}(11) \mathrm{F}(13)$ & $41.98 \pm 0.60$ & $555 \pm 8$ & $258 \pm 9 a$ & $130 \pm 6 b$ & $0.321 \pm 0.010 \mathrm{a}$ & $0.247 \pm 0.009 b$ \\
\hline \multicolumn{8}{|l|}{$R R G-60$} \\
\hline $\mathrm{nn}$ & $\mathrm{M}(5) \mathrm{F}(2)$ & $26.70 \pm 0.72$ & $346 \pm 9$ & $189 \pm 9 a b$ & $155 \pm 6 b$ & $0.411 \pm 0.017$ & $0.447 \pm 0.021$ \\
\hline $\mathrm{Nn}$ & $\mathrm{M}(4) \mathrm{F}(7)$ & $25.54 \pm 0.58$ & $325 \pm 7$ & $177 \pm 8 a$ & $134 \pm 5 a$ & $0.403 \pm 0.013$ & $0.417 \pm 0.017$ \\
\hline NN & $\mathrm{M}(2) \mathrm{F}(12)$ & $27.12 \pm 0.51$ & $341 \pm 6$ & $202 \pm 7 b$ & $142 \pm 4 a b$ & $0.426 \pm 0.012$ & $0.420 \pm 0.015$ \\
\hline \multicolumn{8}{|l|}{$R R G-90$} \\
\hline nn & $\mathrm{M}(3) \mathrm{F}(1)$ & $29.81 \pm 1.06$ & $381 \pm 14$ & $194 \pm 28$ & $148 \pm 10 \mathrm{~b}$ & $0.382 \pm 0.016$ & $0.388 \pm 0.010$ \\
\hline $\mathrm{Nn}$ & $\mathrm{M}(2) \mathrm{F}(4)$ & $29.47 \pm 0.87$ & $376 \pm 11$ & $209 \pm 23$ & $129 \pm 8 \mathrm{ab}$ & $0.365 \pm .0013$ & $0.343 \pm 0.009$ \\
\hline NN & $\mathrm{M}(1) \mathrm{F}(5)$ & $29.83 \pm 0.87$ & $380 \pm 11$ & $218 \pm 23$ & $116 \pm 8 a$ & $0.375 \pm 0.013$ & $0.305 \pm 0.009$ \\
\hline
\end{tabular}

${ }^{¥}$ Numbers within a column and study followed by a different letter were significantly different $(\mathrm{P}<0.05)$.

${ }^{\S} \mathrm{B}=$ barrow, $\mathrm{F}=$ female, $\mathrm{M}=$ male.

*Adjusted for the effects of a low protein diet on nitrogen excretion and heat production as reported by LE BELLEGO et al. (2001). 
The gross efficiency of feed utilization for growth was improved during compensatory growth and was accompanied by an increase in the efficiency of protein deposition. However, compensatory growth had no effect on the efficiency of energy deposition. A study by LOVATTO et al. (2006) concluded that compensatory growth of pigs following a period of feed restriction does not appear to be related to a change in the metabolic utilization of energy for gain. GÄDEKEN et al. (1983) also observed that pigs undergoing compensatory growth had increased protein deposition that was attributed to higher protein digestibility and higher efficiency of utilization, however there was no difference in the efficiency of utilization of metabolizable energy when compared to control pigs. Measurements of protein turnover during compensatory growth suggest that muscle protein synthesis increases at a faster rate after the change to ad libitum feeding and reaches the same level as control pigs before muscle protein degradation (THERKILDSEN et al., 2002).

Ractopamine has been shown to improve the efficiency of feed utilization in pigs (WATKINS et al., 1990; HE et al., 1993; DUNSHEA et al., 1998). In the present study, ractopamine treatment resulted in an improvement in the efficiency of protein deposition. The effect was more pronounced during compensatory growth. It appears that both compensatory growth and ractopamine improve the efficiency of protein deposition in part due to the increase in protein deposition - see Fig. 1. Ractopamine resulted in a reduction in the efficiency of energy deposition, with the effect being primarily in the pigs that were fed ad libitum throughout the study. It is unlikely that the reduction in the efficiency deposition associated with ractopamine treatment was the result of an increase in basal metabolic rate. YEN et al. (1991) reported that ractopamine treatment had no effect on postprandial whole-animal heat production in pigs. In addition, a study by FERNÁNDEZ et al. (1998) found that salbutamol did not alter energy metabolism in swine and concluded that the detected differences in energy retention were a consequence of the modified protein and fat deposition pattern.

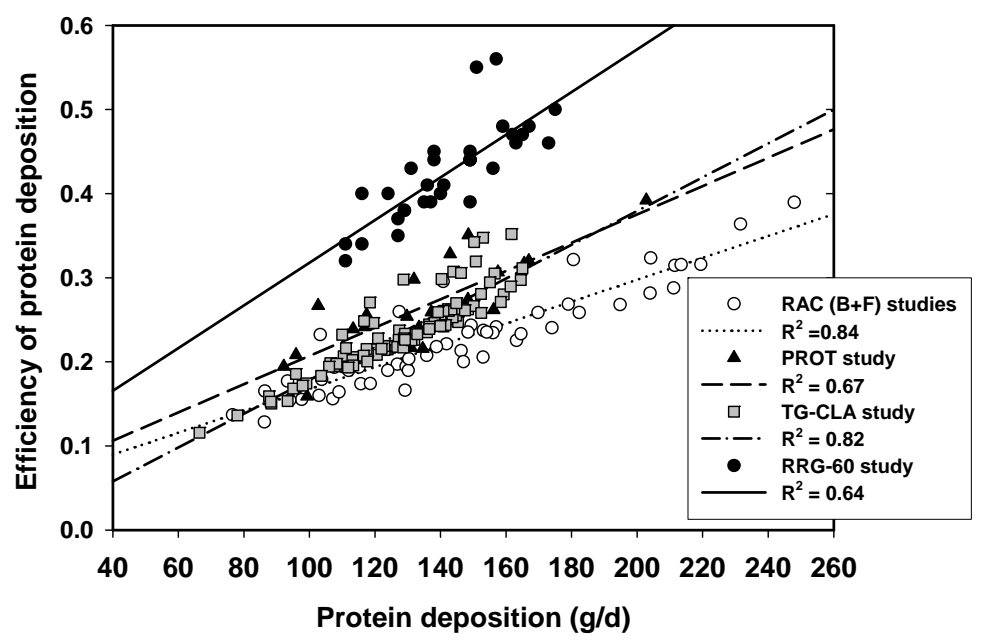

Fig. 1: Relationship between the rate of protein deposition and the efficiency of protein deposition among the various study groups. (Beziehungen von Proteinansatzrate und Proteinansatzeffizienz zwischen den verschiedenen Versuchsgruppen) 
For pigs fed at the calculated intake level, the MC-LP group (PROT study) had higher efficiency for both energy and protein deposition compared to the C or MC-HP groups. These differences are consistent with the effects of a low protein diet on nitrogen excretion and heat production as reported by LE BELLEGO et al. (2001).

In the TG/CLA study, the $\mathrm{k}_{\mathrm{g}}$ was higher $(\mathrm{P}<0.05)$ for the C-CO pigs compared to the CCLA or T-CLA pigs, while the T-C pigs were intermediate (Tab. 3). Overall, the $\mathrm{k}_{\mathrm{g}}$ was higher for pigs fed the CO diet compared to those fed the CLA diet $(\mathrm{CO}=0.35$, $>$ CLA $=$ $0.32, \mathrm{P}<0.05)$. This is consistent with the CLA induced increase in energy expenditure observed in mice (WEST et al. 2000; TERPSTRA et al. 2002). There was no difference in $\mathrm{k}_{\mathrm{g}}$ based on genotype or sex. There was a close relationship between $\mathrm{k}_{\mathrm{g}}$ and the rate of fat accretion, independent of diet or genotype (Fig. 2). Thus, according to this model, a more efficient utilization of energy allowed more energy to be available for fat deposition. The $\mathrm{PE}$ was higher $(\mathrm{P}<0.05)$ in the $\mathrm{T}-\mathrm{CO}$ and $\mathrm{T}$-CLA pigs compared to the $\mathrm{C}-\mathrm{CO}$ and $\mathrm{C}-\mathrm{CLA}$ pigs; hence there was a significant genotype effect. There was also a significant sex effect (females $=0.24$, $>$ barrows $=0.22, \mathrm{P}<0.05$ ), but no diet (CLA) effect.

The utilization of dietary energy for fat $\left(\mathrm{k}_{\mathrm{f}}\right)$, protein $\left(\mathrm{k}_{\mathrm{p}}\right)$ or total body growth $\left(\mathrm{k}_{\mathrm{g}}\right)$ during the 30-60-90 kg growth phases by pigs of different ryoanodine receptor 1 genotypes (RRG studies) is shown in Tab. 4. There was a trend toward a decrease in the utilization of energy for fat deposition in favor of protein deposition by the $n n$ and $\mathrm{Nn}$ genotype relative to the $N N$ genotype. However, the only significant difference appeared during

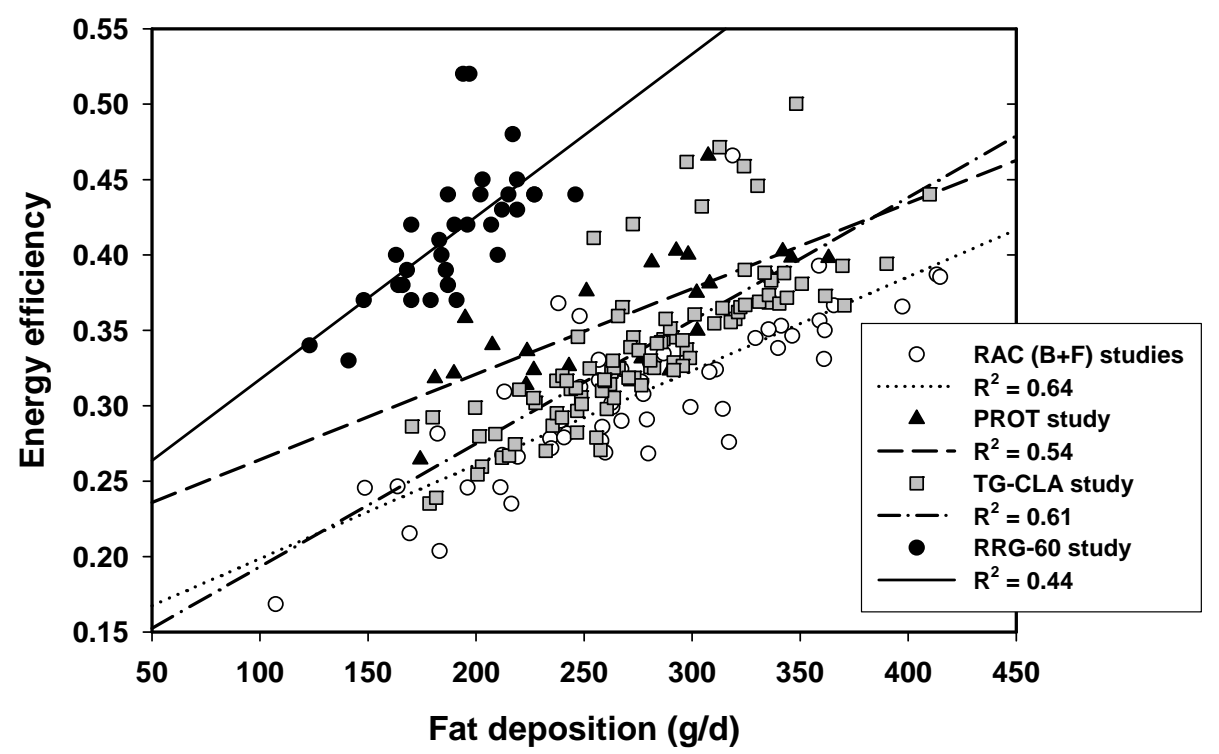

Fig. 2: Relationship between the rate of fat deposition and the efficiency of energy deposition among the various study groups. (Beziehungen von Fettansatzrate und Energieansatzeffizienz zwischen den verschiedenen Versuchsgruppen).

growth from 30 to $90 \mathrm{~kg}$, when the $\mathrm{nn}$ pigs deposited more protein relative to energy intake than did the $N N$ pigs, with the $N n$ pigs being intermediate. There were no differences among genotypes in $\mathrm{k}_{\mathrm{g}}$. Although metabolic events associated with the ryanodine receptor 1 defect would suggest that the $n n$ pigs might be less efficient with 
respect to energy utilization, DXA results revealed no differences in $\mathrm{k}_{\mathrm{f}}$ or $\mathrm{k}_{\mathrm{g}}$. In fact, during growth from 30 to $90 \mathrm{~kg}$, protein deposition per MJ of energy intake was more efficient in the $n n$ pigs. However, $\mathrm{k}_{\mathrm{g}}, \mathrm{k}_{\mathrm{f}}$ and $\mathrm{k}_{\mathrm{p}}$ decreased $(\mathrm{P}<0.05)$ in all three genotypes in the 30-60 kg growth phase when compared to the 60-90 kg growth phases.

Table 4

Efficiency of energy utilization for fat, protein or total body growth in of pigs of different ryanodine receptor genotypes at 30, 60 and 90 kg (Effizienz der Energieverwertung für Fett-, Protein- und Körpermassewachstum bei Schweinen mit unterschiedlichen Ryanodinrezeptor-Genotypen)

\begin{tabular}{llllll}
\hline $\begin{array}{l}\text { Weight } \\
\text { group }\end{array}$ & Genotype & Number & $\begin{array}{l}\text { Fat } \\
(\mathrm{g} / \mathrm{MJ})\end{array}$ & $\begin{array}{l}\text { Protein } \\
(\mathrm{g} / \mathrm{MJ})\end{array}$ & $\begin{array}{l}\text { Total } \\
(\mathrm{g} / \mathrm{MJ})\end{array}$ \\
\hline $30-60 \mathrm{~kg}$ & $\mathrm{nn}$ & 7 & $6.98 \pm 0.36$ & $5.71 \pm 0.27 \mathrm{a}$ & $30.50 \pm 1.23$ \\
& $\mathrm{Nn}$ & 11 & $6.95 \pm 0.29$ & $5.32 \pm 0.22 \mathrm{a}$ & $28.93 \pm 0.98$ \\
$60-90 \mathrm{~kg}$ & $\mathrm{NN}$ & 14 & $7.55 \pm 0.25$ & $5.36 \pm 0.19 \mathrm{a}$ & $29.72 \pm 0.87$ \\
& $\mathrm{nn}$ & 4 & $5.32 \pm 0.76$ & $4.01 \pm 0.31 \mathrm{a}$ & $21.71 \pm 1.68$ \\
& $\mathrm{Nn}$ & 6 & $6.05 \pm 0.69$ & $3.75 \pm 0.29 \mathrm{a}$ & $21.32 \pm 1.53$ \\
$30-90 \mathrm{~kg}$ & $\mathrm{NN}$ & 4 & $6.54 \pm 0.69$ & $3.51 \pm 0.29 \mathrm{a}$ & $20.88 \pm 1.53$ \\
& $\mathrm{nn}$ & 6 & $6.11 \pm 0.42$ & $4.98 \pm 0.25 \mathrm{a}$ & $26.55 \pm 2.72$ \\
& $\mathrm{Nn}$ & $6.54 \pm 0.39$ & $4.46 \pm 0.23 \mathrm{ab}$ & $24.82 \pm 2.49$ \\
& $\mathrm{NN}$ & 6 & $7.02 \pm 0.39$ & $4.17 \pm 0.23 \mathrm{~b}$ & $28.16 \pm 2.49$ \\
\hline
\end{tabular}

From this study ( $R R G$ ), inferences regarding the measurement of energetic efficiency and its association with the ryanodine receptor 1 defect would be difficult considering the small number of pigs observed during the $60-90 \mathrm{~kg}$ growth phase. However, the results shown in Tab. 3 suggest that energetic efficiency during the 30-60 kg growth phase decreased in the following order $N N>N n \geq n n$. One could speculate that the reduced energy efficiency in pigs carrying the defective $n$ allele may be due to higher maintenance energy requirements resulting from partial energy decoupling probably caused by latent increased intracellular $\mathrm{Ca}^{2+}$ concentration and a higher energetic cost for increased protein synthesis. Reduced lipid deposition could result from less available energy and/or indirect activation of the lipolytic system via catecholamine induced cAMP turnover.

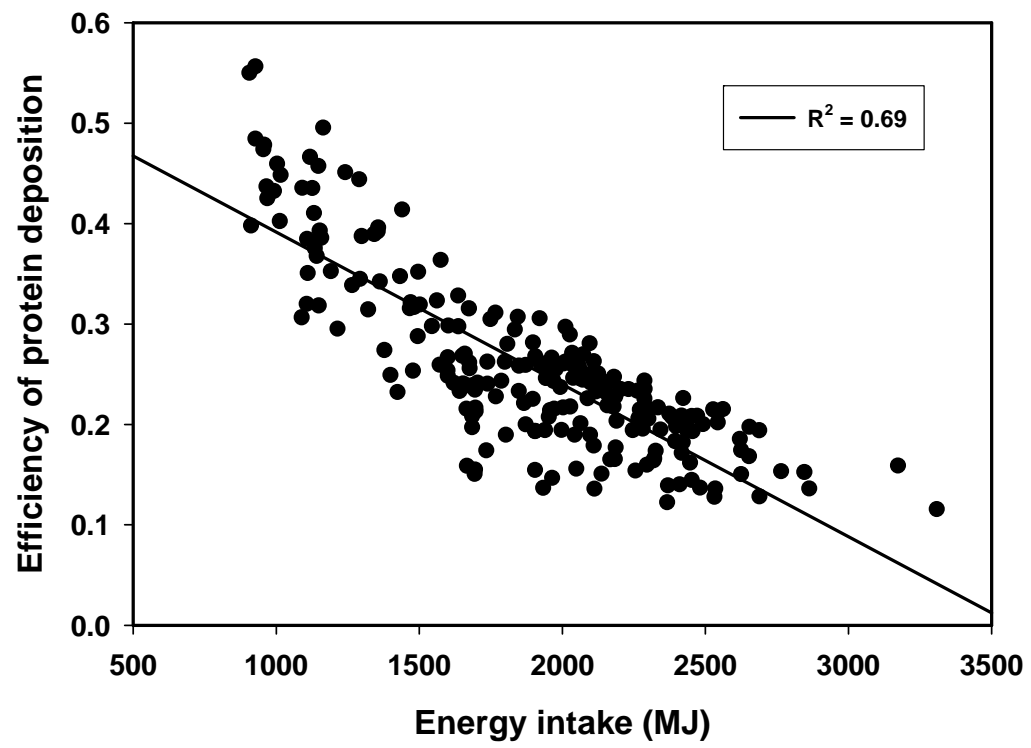

Fig. 3: Relationship between energy intake and efficiency of protein deposition (all pigs, $n=223$ ) (Beziehung zwischen Energieaufnahme und Effizienz des Proteinansatzes (alle Schweine, $\mathrm{n}=223$ )). 
Regression analysis of relationship between energy efficiency and fat deposition rate and between protein efficiency and protein deposition rate are shown in Tab. 5. In both cases, the relationships were fairly uniform for each study, resulting in overall high correlations within each study. However, between studies differences were more obvious. These differences appear more clearly in Fig. 1 and 2, where in both cases the younger pigs (RRG-60 study) were clearly more efficient relative to deposition rate. Among the older pigs (those started at $60 \mathrm{~kg}$ ), it is likely that differences in intake level contributed to the differences between studies. There was also a close inverse relationship $\left(R^{2}=0.69\right)$ between the efficiency of protein accretion and the total energy intake (Fig. 3). The reduction in efficiency of protein accretion with increasing energy intake is consistent with the results of BIKKER (1994).

Table 5

Regression analysis of relationship between energy efficiency and fat deposition rate and between protein efficiency and protein deposition rate $\left(Y=a+b^{*} X\right)$. [Regressionsanalyse für die Beziehung zwischen Energieeffizienz und Fettansatzrate sowie zwischen Proteineffizienz und Proteinansatzrate $(Y=a+b * X)]$

\begin{tabular}{|c|c|c|c|c|c|c|c|}
\hline \multicolumn{2}{|c|}{ Description } & \multicolumn{3}{|c|}{$\begin{array}{l}\text { Energy efficiency }(\mathrm{Y}) \text { vs. fat } \\
\text { deposition rate }(\mathrm{X})(\mathrm{g} / \mathrm{d})\end{array}$} & \multicolumn{3}{|c|}{$\begin{array}{l}\text { Protein efficiency (Y) vs. protein } \\
\text { deposition rate }(\mathrm{X})(\mathrm{g} / \mathrm{d})\end{array}$} \\
\hline Study/Group & $\operatorname{Sex}^{\S} /(\mathrm{n})$ & Intercept & Slope $\left(\mathrm{E}^{-4}\right)$ & $\mathrm{r}$ & Intercept & Slope $\left(\mathrm{E}^{-3}\right)$ & $\mathrm{r}$ \\
\hline$R A C-B+F$ & (54) & 0.136 & 6.26 & 0.80 & 0.038 & 1.30 & 0.92 \\
\hline \multicolumn{8}{|l|}{$R A C-B$} \\
\hline A & $\mathrm{B}(8)$ & 0.091 & 7.52 & 0.83 & 0.030 & 1.54 & 0.92 \\
\hline MA & $\mathrm{B}(9)$ & 0.165 & 5.10 & 0.53 & 0.042 & 1.29 & 0.67 \\
\hline A-R & B(9) & 0.104 & 6.59 & 0.89 & -0.020 & 1.53 & 0.96 \\
\hline MA-R & $\mathrm{B}(8)$ & 0.213 & 3.73 & 0.78 & -0.091 & 1.88 & 0.96 \\
\hline \multicolumn{8}{|l|}{$R A C-F$} \\
\hline A & $F(5)$ & -0.255 & 22.41 & 0.99 & -0.019 & 2.10 & 0.80 \\
\hline MA & $\mathrm{F}(5)$ & 0.064 & 10.96 & 0.92 & 0.017 & 1.73 & 0.94 \\
\hline A-R & $\mathrm{F}(5)$ & 0.078 & 7.91 & 0.96 & 0.008 & 1.49 & 0.99 \\
\hline MA-R & $\mathrm{F}(5)$ & 0.199 & 2.33 & 0.28 & -0.012 & 1.63 & 0.99 \\
\hline PROT & (24) & 0.208 & 5.57 & 0.73 & $0.039^{*}$ & $1.68^{*}$ & $0.82^{*}$ \\
\hline C & $\mathrm{B}(8)$ & 0.150 & 7.94 & 0.92 & -0.002 & 1.91 & 0.98 \\
\hline MC-HP & B(8) & 0.273 & 2.77 & 0.53 & -0.054 & 2.20 & 0.85 \\
\hline MC-LP & B(8) & 0.294 & 3.09 & 0.31 & -0.048 & 3.41 & 0.90 \\
\hline MC-LP* & & $0.194^{*}$ & $4.80^{*}$ & $0.46^{*}$ & $-0.028^{*}$ & $2.48^{*}$ & $0.94^{*}$ \\
\hline$T G-C L A$ & (97) & 0.112 & 8.16 & 0.78 & -0.022 & 2.01 & 0.90 \\
\hline C-CO & $\mathrm{B}(10)$ & 0.101 & 8.27 & 0.84 & -0.009 & 1.87 & 0.87 \\
\hline $\mathrm{C}-\mathrm{CO}$ & $F(15)$ & 0.082 & 9.07 & 0.64 & 0.002 & 1.81 & 0.79 \\
\hline C-CLA & $\mathrm{B}(12)$ & -0.053 & 13.72 & 0.78 & -0.006 & 1.87 & 0.92 \\
\hline C-CLA & $F(13)$ & 0.018 & 11.68 & 0.91 & 0.023 & 1.62 & 0.86 \\
\hline $\mathrm{T}-\mathrm{CO}$ & $\mathrm{B}(10)$ & 0.181 & 5.49 & 0.91 & -1.012 & 1.87 & 0.99 \\
\hline $\mathrm{T}-\mathrm{CO}$ & $F(13)$ & 0.079 & 10.53 & 0.77 & -0.409 & 4.78 & 0.87 \\
\hline T-CLA & $\mathrm{B}(11)$ & 0.119 & 7.96 & 0.72 & -0.034 & 2.10 & 0.93 \\
\hline T-CLA & $\mathrm{F}(13)$ & 0.145 & 6.67 & 0.89 & -0.011 & 1.87 & 0.96 \\
\hline$R R G-60$ & (32) & 0.210 & 10.78 & 0.66 & 0.066 & 2.52 & 0.64 \\
\hline$R R G-90$ & (16) & 0.288 & 4.06 & 0.72 & 0.079 & 0.54 & 0.59 \\
\hline
\end{tabular}

${ }^{\mathrm{s}} \mathrm{B}=$ barrow, $\mathrm{F}=$ female, $\mathrm{M}=$ male

*Adjusted for the effects of a low protein diet on nitrogen excretion and heat production as reported by LE BELLEGO et al. (2001).

In conclusion, DXA can be used to replace the comparative slaughter technique for measuring energy and protein deposition in pigs, thus providing a more direct 
measurement that requires fewer animals. This technique is useful for identifying differences in energy and protein deposition in pigs of different genotypes or when subjected to various dietary treatments.

\section{References}

BIKKER, P.; KARABINAS, V.; VERSTEGEN, M.W.A.; CAMPBELL, R.G.:

Protein and lipid accretion in body components of growing gilts (20 to 45 kilograms) as affected by energy intake. J. Anim. Sci. 73 (1995), 2355-2363

BOUTHEGOURD, J.C.; EVEN, P.C.; GRIPOIS, D.; TIFFON, B.; BLOUQUIT, M.F.; ROSEAU, S.; LUTTON, C.; TOME, D.; MARTIN, J.C.:

A CLA mixture prevents body triglyceride accumulation without affecting energy expenditure in Syrian hamsters. J. Nutr. 132 (2002), 2682-2689

BRENIG, B.; BREM, G.:

Molecular cloning and analysis of the porcine "halothane” gene. Arch. Tierz., Dummerstorf 35 (1992), 129-135

CARR, S.N.; IVERS, D.J.; ANDERSON, D.B.; JONES, D.J.; MOWREY, D.H.; ENGLAND, M.B.; KILLEFER, J.;

RINCKER, P.J.; MCKEITH, F.K.:

The effects of ractopamine hydrochloride on lean carcass yields and pork quality characteristics. J. Anim. Sci. 83 (2005), 2886-2893

DECANNIERE, C.; VAN HECKE, P.; VANSTAPEL F.; VILLÉ, H.; GEERS, R.:

Metabolic response to halothane in piglets susceptible to malignant hyperthermia: an in vivo ${ }^{31} \mathrm{P}-\mathrm{NMR}$ study. J. Appl. Physiol. 75 (1993), 955-962

DUGAN, M.E.R.; AALHUS, J.L.; SCHAFFER, A.L.; KRAMER, J.K.G.:

The effect of conjugated linoleic acid on fat to lean repartitioning and feed conversion in pigs. Can. J. Anim. Sci. 77 (1997), 723-725

DUNSHEA, F.R.; KING, R.H.; EASON, P.J.; CAMPBELL, R.G.: Interrelationships between dietary ractopamine, energy intake, and sex in pigs. Aust. J. Agric. Res. 49 (1998), 565-574

FERNÁNDEZ, J.A.; OKSBJER, G.N.; JØRGENSEN, H.:

Effect of salbutamol on body composition and energy utilization in growing pigs fed two levels of protein. In: Energy Metabolism of Farm Animals (Ed.: K. McCracken, F.F. Unsworth and A.R.G. Wylie), CAB International, Wallingford, UK (1998), 249-252

GÄDEKEN, D.; BOHME, H.; OSLAGE, H.J.:

Protein and energy metabolism in growing pigs as influenced by compensatory growth. Archiv für Tierernährung 33 (1983), 125-140

FUJII J.; OTSU, K. ;ZORZATO, F.; DE LEON, S.; KHANNA, V.K.; WEILER, J.; O'BRIEN, P.J.; MACLENNAN, D.H. Identification of a mutation in the porcine ryanodine receptor that is associated with malignant hyperthermia. Science 253 (1991), 448-451

GEERS, R.; DECANNIERE, C.; ROSIER, A.; VILLE, H.; VAN HECKE, P.; VANDESANDE, F.; JOURQUIN, J.: Variability of energy metabolism and nuclear $\mathrm{T}_{3}$-receptors within the skeletal muscle tissue of pigs different with respect to the halothane gene. J. Anim. Sci. 74 (1996), 717-722

GEERS, R.; DECANNIERE, C.; VILLÉ, H.; VAN HECKE, P.; GOEDSEELS, V.;VANSTAPEL, F.; BOSSCHAERTS, L.; DE LEY, J.; ZHANG, W.; JANSSENS, S: In vivo muscle ${ }^{31} \mathrm{P}$ nuclear magnetic resonance spectroscopy during treatment of halothane-sensitive and halothane-nonsensitive pigs. Am. J. Vet. Res. 53 (1992), 613-616

HE, P.; AHERNE, F.X.; THOMPSON, J.R.; SCHAEFER, A.L.; MERRILL, J.K.:

Effect of ractopamine on carcass characteristics and joint cartilage soundness in finishing pigs. Can. J. Anim. Sci. 73 (1993), 169-176

KLEIBER, M.: The Fire of Life. John Wiley and Sons, NY, USA (1961)

KYRIAZAKIS, I.; EMMANS, G. C.:

The effects of varying protein and energy intakes on the growth and body composition of pigs 2 . The effects of varying both energy and protein intake. Br. J. Nutr. 68 (1992), 615-625 
LE BELLEGO, L.; VAN MILGEN, J.; DUBOIS, S.; NOBLET, J.:

Energy utilization of low-protein diets in growing pigs. J. Anim. Sci. 79 (2001), 1259-1271

LOVATTO, P.A.; SAUVANT, D.; NOBLET, J.; DUBOIS, S.; VAN MILGEN, J.:

Effects of feed restriction and subsequent refeeding on energy utilization in growing pigs. J. Anim. Sci. 84 (2006), 3329-3336

MERSMANN, H.J.; MACNEIL, M.D.; SEIDEMAN, S.C.; POND, W.G.:

Compensatory growth in finishing pigs after feed restriction. J. Anim. Sci. 64 (1987), 752-764

MITCHELL, A.D.; SOLOMON, M.B.; STEELE, N.C.:

Response of low and high protein select lines of pigs to the feeding of the beta-adrenergic agonist ractopamine (phenethanolamine). J. Anim. Sci. 68 (1990), 3226-3232

MITCHELL, A.D.; SCHOLZ, A.M.:

Dual-energy x-ray absorptiometry (DXA) analysis of growth and body composition of pigs of different ryanodine receptor genotypes. Arch. Tierz., Dummerstorf 40 (1997), 11-21

MITCHELL, A.D.; SCHOLZ, A.M.; EVOCK-CLOVER, C.M.:

The application of dual energy X-ray absorptiometry for live animal and carcass evaluation of pigs. 47th Ann. Meeting of Europ. Assoc. Anim. Prod., Lillehammer. PS5.22 (1996), pp 4

MITCHELL, A.D.; SCHOLZ, A.M.; PURSEL, V.:

Prediction of the body composition of pigs based on cross-sectional region analysis of dual energy X-ray absorptiometry (DXA) scans. Arch. Tierz. 45 (2002), 535-545

MITCHELL, A.D.; PURSEL, V.G.; ELSASSER, T.H.; MCMURTRY, J.P.; BEE, G.:

Effects of dietary conjugated linoleic acid on growth and body composition of control and IGF-I transgenic pigs. Anim. Res. 54 (2005), 395-411

MULLER, H.L.; KIRCHGESSNER, M.; ROTH, F.X.; STANGL, G.I.;

Effect of conjugated linoleic acid on energy metabolism in growing-finishing pigs. Anim. Physiol. Anim. Nutr. 83 (2000), 85-94

NRC:

Nutrient Requirements of Swine. National Research Council, National Academy Press, Washington, DC, USA (1988), pp 8

OSTROWSKA, E.; SUSTER, D.; MURALITHARAN, M.; CROSS, R.F.; LEURY, B.J.; BAUMAN, D.E.;

DUNSHEA, F.R.:

Conjugated linoleic acid decreases fat accretion in pigs: evaluation by dual-energy X-ray absorptiometry. B.

J. Nutr. 89 (2003), 219-229

OTTEN, W.; EICHINGER, H.M.; GOLDBER,G.M.:

Effects of different Malignant Hyperthermia genotypes on energy metabolism in swine. 44th Annual Meeting of the EAAP, Aarhus (1993)

PARK, Y.; ALBRIGHT, K.J.; LIU, W.; STORKSON, J.M.; COOK, M.E.; PARIZA, M.W.:

Effect of conjugated linoleic acid on body composition in mice. Lipids 32 (1997), 853-858

PURSEL, V.G.; MITCHELL, A.D.; BEE, G.; ELSASSER, T.H.; MCMURTRY, J.P.; WALL, R.J.; COLEMAN, M.E.; SCHWARTZ, R.J.:

Growth and tissue accretion rates of swine expressing an insulin-like growth factor I transgene. Anim.

Biotechnology 15 (2004), 33-45

SAINZ, R.D.; WOLFF, J.E.:

The effects of the beta-agonist, cimaterol, on growth, body composition and energy expenditure in rats. Br. J. Nutr. 60 (1988), 85-90

SAGGAU, E; BEYER, M.; KLEIN, M; SCHADEREIT, R.; DERNO, M.; JENTSCH, W.; SCHOLZE, H. Effects of dietary protein quality on energy metabolism and thyroid hormone status in growing pigs. Arch. Tierz.43 (2000), 633-647

SCHOLZ, A.M.; FÖRSTER, M.

Accuracy of dual energy X-ray absorptiometry (DXA) for the determination of the body composition of pigs in vivo. Arch. Tierz. 49 (2006), 462-476

SCHOLZ, A.; MITCHELL, A.D.; WANG, P.C.; SONG, H.; YAN, Z.: Muscle metabolism and body composition of pigs with different ryanodine receptor genotypes studied by means of ${ }^{31} \mathrm{P}$ nuclear magnetic resonance spectroscopy and ${ }^{1} \mathrm{H}$ magnetic resonance imaging. Arch. Tierz., Dummerstorf 38 (1995), 539-552

TERPSTRA, A.H.; BEYNEN, A.C.; EVERTS, H.; KOCSIS, S.; KATAN, M.B.; ZOCK, P.L.:

The decrease in body fat in mice fed conjugated linoleic acid is due to increases in energy expenditure and energy loss in the excreta. J. Nutr. 32 (2002), 940-945 
THERKILDSEN, M.; RIIS, B.; KARLSSON, A.; KRISTENSEN, L.; ERTBJEER, G.P.; RURSLOW, P.P.; DALL, A.; ASLYNG, M.; OKSBJER, G.N.:

Compensatory growth response in pigs, muscle protein turn-over and meat texture: effects of restriction/realimentation period. Anim. Sci.75 (2002), 367-377

WATKINS, L.E.; JONES, D.J.; MOWREY, D.H.; ANDERSON, D.B.; VEENHUIZEN, E.L.:

The effect of various levels of ractopamine hydrochloride on the performance and carcass characteristics of finishing swine. J. Anim. Sci. 68 (1990), 3588-3595

WEST, D.B.; BLOHM, F.Y.; TRUETT, A.A.; DELANY, J.P.:

Conjugated linoleic acid persistently increases total energy expenditure in AKR/J mice without increasing uncoupling protein gene expression. J. Nutr. 130 (2000), 2471-2477

YEN, J.T.; NIENABER, J.A.; KLINDT, J.; CROUSE, J.D.:

Effect of ractopamine on growth, carcass traits, and fasting heat production of U.S. contemporary crossbred and Chinese Meishan pure- and crossbred pigs. J. Anim. Sci. 69 (1991), 4810-4822

Received: 2007-12-28

Accepted: 2008-01-27

Authors addresses

Dr. ALVA D. MITCHELL*, USDA-Agricultural Research Service, Animal Biosciences and Biotechnology Laboratory, BELTSVILLE, MD 20705, USA

Priv.-Doz. Dr. ARMIN M. SCHOLZ, Livestock Center Oberschleißheim, Veterinary Faculty of the Ludwig-Maximilians University Munich, Sankt-Hubertusstrasse 12, D-85764 OBERSCHLEISSHEIM

email: armin.scholz@lvg.vetmed.uni-muenchen.de

*Corresponding author

email: alva.mitchell@ars.usda.gov 